\title{
ANALISIS MATERI BUKU SISWA SEJARAH KEBUDAYAAN ISLAM MA KELAS XI TERBITAN KEMENAG KURIKULUM 2013
}

\author{
Ani Roisatul Muna \\ Universitas Muhammadiyah Malang \\ Email: aniiroisatul@gmail.com
}

\begin{abstract}
Abstrak
Tujuan dari penelitian ini adalah untuk menemukan dan menganalisis kelayakan isi materi buku siswa mata pelajaran Sejarah Kebudayaan Islam pada jenjang Madrasah Aliyah kelas XI yang diterbitkan oleh Kementerian Agama dalam Kurikulum 2013. Penelitian ini menggunakan penelitian kepustakaan (library research), dengan teknik analisis deskriptif. Hasil dari penelitian ini menunjukkan bahwa buku siswa mata pelajaran Sejarah Kebudayaan Islam telah menyajikan pembahasan yang cukup jelas, ringkas, dan mudah dipahami serta bisa mengedukasi dengan cukup baik. Dengan demikian, diharapkan bagi guru bisa menjadi pendidik yang berkualitas dan baik, sehingga bisa mencapai tujuan pembelajaran dan meningkatkan kualitas pendidikan.
\end{abstract}

Kata Kunci: Sejarah Kebudayaan Islam, Kurikulum 2013

\begin{abstract}
The purpose of this study was to find and analyze the appropriateness of the contents of the book material of Islamic Cultural History students at the XI grade Madrasah Aliyah level published by the Ministry of Religion in 2013 Curriculum. This study used library research, with descriptive analysis techniques. The results of this study indicate that the student book on the subject of Islamic Cultural History has presented a discussion that is quite clear, concise, and easy to understand and can educate quite well. Thus, it is expected that teachers can become qualified and good educators, so that they can achieve learning goals and improve the quality of education.
\end{abstract}

Keywords: Islamic Cultural History, 2013 Curriculum

\section{PENDAHULUAN}

Pendidikan ialah proses dua arah yang melibatkan adanya pemberian pengetahuan sebagai bentuk pemberian petunjuk dan peringatan, serta sekaligus sebagai upaya dalam memperoleh pengetahuan untuk mendapatkan ketakwaan, tidak menonjolkan diri dan kesombongan (intelektual) (A'la, 2006). Pendidikan juga dapat dimaknai dengan usaha sadar untuk menumbuhkan suasana belajar dan proses pembelajaran agar peserta didik bisa aktif mengembangkan potensi diri untuk memiliki kekuatan spiritual keagamaan, pengendalian diri, kepribadian, kecerdasan, akhlak mulia, serta keterampilan yang dibutuhkan bagi dirinya dan masyarakat (Tirtarahardja dan Sulo, 2005).

Salah satu dasar utama dari sebuah pendidikan adalah untuk mengajar kebudayaan melewati generasi. Di era sekarang ini, semua negara telah berusaha dan berlomba-lomba untuk meningkatkan kualitas pendidikannya, karena kualitas pendidikan merupakan salah satu indikator untuk meningkatkan kesejahteraan masyarakat pada suatu negara. Dengan melalui pendidikan yang 
Analisis Materi Buku Siswa ..... Ani Roisatul Muna

berkualitas akan menciptakan sumber daya manusia yang lebih berkualitas dan mampu mengelola sumber daya alam secara efektif dan efisien. Dengan adanya sumber daya yang berkualitas, tentunya produktivitas negara juga ikut meningkat, sehingga diharapkan untuk mampu meningkatkan daya saing dan kesejahteraan masyarakat. Peningkatan kualitas pendidikan merupakan segala proses yang dilakukan secara dinamis serta berkesinambungan dalam rangkan meningkatkan kualitas pendidikan dan berbagai faktor yang berhubungan dengannya, dalam upaya pencapaian tujuan pendidikan secara efektif dan efisien (Wakhid, 2017).

Begitu juga dengan negara Indonesia yang telah berusaha untuk meningkatkan kualitas pendidikannya sebagaimana yang diamanatkan Undang-Undang Nomor 20 Tahun 2003 tentang Sistem Pendidikan Nasional bertujuan untuk mewujudkan "berkembangnya potensi peserta didik agar menjadi manusia yang beriman dan bertakwa kepada Tuhan Yang Maha Esa, berakhlak mulia, sehat, berilmu, cakap, kreatif, mandiri dan menjadi warga negara yang demokratis serta bertanggung jawab" (UU Nomor 20, 2003). Untuk menyelenggarakan suatu pendidikan guna mencapai tujuan pendidikan tersebut dibutuhkan suatu kurikulum yang matang (Wakhid,2017).

Perlu kita ketahui bahwa, kurikulum di Indonesia yang berlaku adalah kurikulum 2013. Kurikulum dinilai merupakan salah satu langkah sentral dan strategis dalam rangka penguatan karakter bangsa Indonesia. Sebab, kurikulum 2013 di Indonesia ini telah mempersiapkan peserta didik dalam menghadapi tantangan-tantangan di masa depan melalui pengetahuan, keterampilan, sikap dan keahlian untuk beradaptasi serta bisa bertahan hidup dalam lingkungan yang senantiasa berubah (Wakhid, 2017). Maka dari itu, kurikulum 2013 diyakini mampu mendorong terwujudnya tujuan pendidikan nasional, yakni "berkembangnya potensi peserta didik agar menjadi manusia yang beriman, dan bertakwa kepada Tuhan Yang Maha Esa, berakhlak mulia, sehat, berilmu, cakap, kreatif, mandiri dan menjadi warga negara yang demokratis serta bertanggung jawab" (Wakhid, 2017).

Dalam menunjang keberhasilan suatu pendidikan dibutuhkan sarana yang bisa menjadi pedoman dalam proses pembelajaran, salah satunya adalah penggunaan buku teks dalam proses pembelajaran. Buku teks merupakan salah satu komponen penting dalam kurikulum 2013 yang digunakan dalam pelaksanaan proses pembelajaran. Buku teks digunakan sebagai sumber memperoleh informasi bagi peserta didik dan pendidik yang berisi bahan / materi, sehingga dapat dimanfaatkan untuk mengetahui apa yang terjadi pada masa lalu, masa sekarang, dan masa depan dan dapat memperluas wawasan bagi pembacanya serta dapat menjadi inspirasi untuk mendapat gagasan yang baru. Penggunaan buku teks dapat membantu proses pembelajaran pada mata pelajaran tertentu, seperti pada mata pelajaran Sejarah Kebudayaan Islam Madrasah Aliyah Kelas XI. Berbagai macam buku teks yang terbit, akan mempermudah bagi guru dalam memilih buku teks sebagai pendamping yang tepat digunakan bagi sekolah untuk menjadi buku pelengkap selain buku siswa yang diterbitkan 
Analisis Materi Buku Siswa ..... Ani Roisatul Muna

oleh pemerintah (Wakhid, 2017). Buku teks merupakan alat bantu yang digunakan oleh guru dan siswa dalam proses pembelajaran. Buku teks akan selalu memegang peranan yang penting dalam pendidikan (Ibrahim dan Syaodih, 2010).

Buku teks yang baik merupakan buku teks yang menyajikan bahan secara lengkap, sistematis, berkualitas, sesuai dengan kebutuhan belajar siswa, serta cara penyajian pada buku tersebut mudah dipahami oleh siswa. Dari segi fisik dan aspek grafis seharusnya buku teks harus disertai dengan ilustrasi yang menarik dalam memperjelas materi yang dibahas, tema pada materi pembelajaran dibuat dengan sebaik mungkin agar dapat menumbuhkan minat baca pada siswa atau bagi siapapun yang membacanya. Selain itu, indikator yang dipaparkan sebelumnya dalam buku teks hendaknya dapat terpenuhi sebagai hasil pembelajaran yang dilakukan (Lubab, 2014)

Menurut Tarigan buku teks atau buku ajar yang ideal ialah buku yang telah memenuhi kriteria sebagai berikut: (a) mempunyai landasan, prinsip dan sudut pandang tertentu yang melandasi konsepkonsep yang digunakan dalam buku teks harus jelas, (b) relevan dengan kurikulum, (c) menarik minat pembaca yang menggunakannya, (d) mampu memberi motivasi kepada para pemakainya, (e) dapat menstimulasi aktivitas peserta didik, (f) membuat ilustrasi yang mampu menarik penggunaannya, (g) pemahaman harus didahului komunikasi yang tepat, (h) isi menunjang mata pelajaran lain, (i) menghargai perbedaan individu, (j) berusaha memantapkan nilai yang berlaku dalam masyarakat, (k) mempertimbangkan aspek linguistik sesuai dengan kemampuan peserta didik yang memakai, (1) menggunakan konsep yang jelas sehingga tidak membingungkan peserta didik, (m) mempunyai sudut pandang (point of view) yang jelas (Dalam Wakhid, 2017)

Dengan demikian, buku ajar yang berkualitas harus memenuhi tiga unsur yaitu kelayakan isi, segi urutan materi, dan kelayakan kebahasaan. Salah satu unsur yang harus diperhatikan yaitu kelayakan isi materi. Isi menyangkut materi yang ada dalam buku ajar sehingga sangat wajar apabila unsur kelayakan isi merupakan unsur utama untuk menentukan kualitas buku. Begitupun juga pada urutan materi dan kelayakan bahasa juga sangat penting untuk diperhatikan agar dapat memudahkan peserta didik dalam memahami buku teks tersebut.

Berdasarkan dari uraian di atas, dapat diketahui bahwa analisis buku siswa adalah hal yang sangat penting, terlebih bagi setiap guru dan calon guru hendaknya membekali dirinya dengan pengetahuan tentang buku teks. Dalam interaksi belajar mengajar tentu tidak hanya diperlukan dari seorang guru dan peserta didik, namun juga diperlukan adanya sebuah alat pembelajaran. Salah satunya ialah buku teks, dengan adanya buku teks tersebut, maka guru dan peserta didik akan terbantu dalam pelaksanaan proses pembelajaran. Buku teks telah memegang peranan yang sangat penting dalam sebuah proses pembelajaran, dimana buku teks dapat mempermudah aktivitas peserta didik dalam belajar. Jika buku teks ditinjau dari segi kualitas, apabila buku teks mempunyai kualitas yang baik maka semakin baik pula proses pembelajaran pada sebuah mata pelajaran yang ditunjang oleh 
Analisis Materi Buku Siswa ..... Ani Roisatul Muna

buku teks tersebut. Dimana kualitas dari buku teks itu dapat dilihat dari tiga unsur yaitu kelayakan isi, segi urutan materi, dan kelayakan kebahasaan. Isi menyangkut materi yang ada dalam buku ajar sehingga sangat wajar apabila unsur kelayakan isi merupakan unsur utama untuk menentukan kualitas buku. Begitupun juga pada segi urutan materi dan kelayakan bahasa juga sangat penting untuk diperhatikan agar dapat memudahkan peserta didik dalam memahami buku teks tersebut. Salah satunya pada buku teks Sejarah Kebudayaan Islam, jika buku teks Sejarah Kebudayaan Islam yang berkualitas, tentunya akan dapat meningkatkan kualitas dalam proses pembelajaran pula, sehingga peserta didik dapat menerima pengajaran Sejarah Kebudayaan Islam dengan hasil yang baik. Dengan demikian berangkat dari permasalahan di atas, maka peneliti mencoba untuk menganalisis materi buku siswa pada mata pelajaran Sejarah Kebudayaan Islam MA kelas XI terbitan Kemenag dengan menggunakan Kurikulum 2013.

\section{METODE PENELITIAN}

Pada penelitian ini menggunakan penelitian kepustakaan (library research), penelitian kepustakaan atau biasa disebut dengan studi pustaka ialah serangkaian kegiatan yang berkenaan dengan metode pengumpulan data pustaka, membaca dan mencatat serta mengolah bahan penelitian. Ciri-ciri penelitian kepustakaan ini adalah: 1) penelitian berhadapan langsung dengan teks atau data angka bukan pengetahuan langsung dari lapangan, 2) penelitian berhadapan langsung bahan dan sumber yang telah tersedia di perpustakaan, 3) data pustaka termasuk data sekunder, berarti peneliti memperoleh bahan dari tangan kedua bukan data orisinil dari tangan pertama di lapangan, 4) peneliti berhadapan langsung dengan data yang tetap yang tidak akan pernah berubah sebab telah terekam dalam angka, tulisan, gambar, rekaman tape, film (Zed, 2008)

Sumber data yang digunakan dibagi menjadi dua kategori yakni, sumber primer dalam penelitian ini adalah Buku Siswa Sejarah Kebudayaan Islam MA kelas XI yang menggunakan kurikulum 2013. Sumber sekunder dalam penelitian ini adalah buku-buku, literatur-literatur yang relevan dan sesuai dengan pokok pembahasan. Sumber sekunder disini menggunakan jurnal, buku, artikel, dan website yang terkait dengan materi Sejarah Kebudayaan Islam MA kelas XI. Kemudian teknik pengumpulan data dengan identifikasi wacana dari buku-buku, makalah atau artikel, jurnal, web (internet), maupun informasi lainnya yang terkait dengan "Buku Siswa Sejarah Kebudayaan Islam MA kelas XI Terbitan Kemenag Kurikulum 2013”. Teknik analisis data yang digunakan dalam penelitian adalah content anlys (analisis isi). Analisis konten adalah teknik penelitian yang digunakan untuk referensi yang replikabel dan valid dari data pada konteksnya (Moleong, 2012). Analisi terhadap "Buku Siswa Sejarah Kebudayaan Islam MA Kelas XI" dilakukan untuk mendapatkan gambaran mengenai keadaan dari unsur-unsur buku teks tersebut. Unsur-unsur tersebut telah dirinci, dipilih, diklasifikasikan, dibandingkan, dan dicocokkan sebagaimana dengan unsur-unsur tersebut. 
Analisis Materi Buku Siswa ..... Ani Roisatul Muna

Setelah data tersebut terkumpul, maka peneliti akan mengolah dan menganalisa data tersebut menggunakan analisis deskriptif. Menurut Winarno S. metode analisis deskriptif adalah metode analisis dengan usaha mengumpulkan dan menyusun suatu data, kemudian dilakukan analisis terhadap data tersebut (Surachmad, 1990).

\section{HASIL DAN PEMBAHASAN}

\section{Pengertian Buku Siswa}

Dalam melakukan suatu proses pembelajaran tentu tidak terlepas dari berbagai komponenkomponen lain yang saling berkaitan, salah satu bentuk komponen dalam proses pembelajaran yakni sumber belajar. Sumber belajar yang digunakan dalam proses pembelajaran telah memiliki berbagai variasi, salah satu bentuk dari sumber belajar ialah buku dan bahan ajar. Salah satu contoh dari bahan ajar adalah buku siswa (Damayanti dkk, 2014).

Buku siswa merupakan buku panduan bagi siswa dalam kegiatan pembelajaran yang memuat materi pelajaran, kegiatan penyelidikan berdasarkan konsep, kegiatan sains, informasi, dan contohcontoh penerapan sains dalam kehidupan sehari-hari. Buku siswa yang dikembangkan orang lain biasanya terdapat ketidakcocokan untuk semua siswa. Maka dari itu, guru dapat memecahkan masalah tersebut dengan cara mengembangkan buku siswa yang disesuaikan dengan karakteristik siswa sebagai sasaran. Hal ini telah sesuai dengan lampiran Permendiknas nomor 16 tahun 2007 tentang Standar Kualifikasi Akademik dan Kompetensi Guru, yaitu bagi guru pada satuan pendidikan jenjang baik dalam tuntutan kompetensi pedagogic maupun kompetensi professional, berkaitan erat dengan kemampuan guru dalam mengembangkan sumber belajar dan bahan ajar (Damayanti dkk, 2014).

Berdasarkan paparan di atas, maka dapat ditarik kesimpulan bahwa yang dimaksud dengan buku pelajaran Sejarah Kebudayaan Islam merupakan buku panduan bagi siswa yang akan digunakan dalam kegiatan pembelajaran yang memuat materi pelajaran, kegiatan penyelidikan berdasarkan konsep, kegiatan sains, informasi, dan contoh-contoh penerapan sains dalam kehidupan sehari-hari. Disamping itu, guru dapat memecahkan masalah terkait adanya ketidakcocokkan masing-masing siswa dengan buku siswa yang diberikan.

\section{Pengertian Sejarah Kebudayaan Islam}

Kata sejarah berasal dari bahasa Arab, yakni kata syajarah dan syajara. Syajarah bermakna pohon, sesuatu yang mempunyai akar, batang, dahan, ranting, daun, bunga, dan buah (Departemen Agama RI, 2009). Semua peristiwa baik yang menyangkut pemikiran, politik, ekonomi, teknologi, dan seni dalam sejarah Islam disebut sebagai kebudayaan. Jadi yang dimaksud kebudayaan ini ialah hasil karya, rasa, dan cipta dari orang-orang muslim (Departemen Agama RI, 2009). Sedangkan kata Islam 
Analisis Materi Buku Siswa ..... Ani Roisatul Muna

berarti bahwa kebudayaan dan sumber nilai tersebut dihasilkan oleh orang-orang Islam. Hal ini juga berarti bahwa kebudayaan Islam merupakan hasil karya, cipta, dan rasa manusia yang menafsirkan tentang agamanya dari waktu ke waktu. SKI sama dengan sejarah kebudayaan lain pada umumnya, yakni bersifat dinamis. Perbedaannya terletak pada sumber nilainya (Departemen Agama RI, 2009).

Arti lain dari sejarah adalah adalah syajara. Ini adalah kata dari bahasa Arab yang berarti perselisihan, pertentangan, pergulatan, atau perlawanan. Dari makna etimologis ini, bisa diperoleh makna terminologis sejarah yang berarti berita atau cerita yang menggambarkan perlawanan atau kelompok dengan kelompok lainnya atau satu gagasan dengan gagasan lainnya yang terjadi dalam satu tempat dan waktu tertentu (Ariyunita dan Rahmaini, 2018). Sedangkan dari segi terminologi, sejarah ialah ilmu yang mempelajari dan menerjemahkan informasi dari laporan dan catatan yang dibuat oleh orang per orang, keluarga dan komunitas tertentu. Pengetahuan mengenai sejarah melingkupi pengetahuan akan kejadian-kejadian yang sudah berlalu serta pengetahuan akan cara berpikir sejarah.

Terdapat pendapat lain mengenai sejarah dari segi etimologi yakni perselisihan, pergulatan atau pertentangan. Sedangkan secara terminologi, sejarah berarti berita atau cerita yang menggambarkan perlawanan satu kelompok dengan kelompok yang lainnya atau satu gagasan dengan gagasan lainnya yang terjadi dalam satu tempat dan waktu tertentu (Basyirudin, 2002). Menurut Imam Barnadib bahwa yang dimaksud dengan kebudayaan ialah sebagai hasil budi daya manusia dalam berbagai bentuk dan sepanjang sejarah sebagai milik manusia yang tidak beku, melainkan selalu berkembang dan berubah (Barnadib, 1987).

Dengan demikian, dapat diartikan bahwa sejarah kebudayaan Islam merupakan ilmu pendidikan Islam, karena mengandung nilai-nilai Islam yang dapat menjadi contoh ataupun suri tauladan bagi umat Islam khususnya, dan umat manusia pada umumnya. Sedangkan yang dimaksud ilmu pendidikan Islam ialah ilmu yang mengkaji pandangan Islam tentang pendidikan dengan menafsirkan nilai-nilai Illahi dan mengkomunikasikan secara timbal balik dengan fenomena dalam situasi pendidikan (Abdurrachman, dkk, 2001). Pengertian dari mata pelajaran sejarah kebudayaan Islam ialah sebuah mata pelajaran yang membahas mengenai ilmu pendidikan Islam, yang telah diberikan pada jenjang Madrasah Ibtidaiyah (MI), Madrasah Tsanawiyah (MTs), dan Madrasah Aliyah (MA). Definisi dari sejarah kebudayaan Islam adalah cerita mengenai perkembangan dari perjalanan hidup orang Islam dari waktu ke waktu dalam beribadah, bermuamalah dan berakhlak serta dalam mengembangkan sistem kehidupan atau menyebarkan ajaran Islam yang dilandasi oleh akidah (Muaripin, 2018). Sedangkan dari segi konsepnya bahwa, sejarah kebudayaan Islam telah membahas kisah nyata perilaku dan kejadian penting orang-orang muslim dahulu sehingga muslim pada masa sekarang bisa menjadikan suri tauladan mengenai segala macam yang baik-baik dalam bertindak dan menegakkan syariat Islam. (Kemenag RI, 2013) 
Analisis Materi Buku Siswa ..... Ani Roisatul Muna

Berdasarkan dari penjelasan di atas dapat diambil kesimpulan bahwa yang dimaksud dengan sejarah kebudayaan Islam merupakan sebuah ilmu pengetahuan tentang pendidikan Islam yang membahas mengenai cerita masa lampau, yang dapat dijadikan sebagai suri tauladan bagi umat Islam. Baik yang membahas mengenai pemikiran, teknologi, sosial, politik, ekonomi, maupun seni, dimana seni dalam sejarah dapat dijadikan sebuah hasil karya, cipta, dan rasa bagi manusia. Sedangkan mata pelajaran sejarah kebudayaan Islam (SKI) telah diajarkan pada setiap jenjang Madrasah Ibtidaiyah (MI), Madrasah Tsanawiyah (MTs), Madrasah Aliyah (MA).

\section{Pengertian Kurikulum 2013}

Pengertian dari kurikulum berasal dari kata "curir" yakni pelari, dan "curere" yang memiliki makna tempat berpacu yang artinya sebagai jarak yang harus ditempuh pelari mulai dari start sampai finish untuk memperoleh medali (Mida, 2013). Menurut Muslih (dalam Paduppai, 1998: 42-43), telah mengatakan bahwa kurikulum ialah seperangkat rencana dan pengaturan isi dan materi pelajaran serta cara yang digunakan sebagai pedoman penyelenggaraan KBM di sekolah (Trianto, 2014). Sedangkan menurut Departemen Pendidikan Nasional (2003:4) telah mengatakan bahwa, kurikulum sebagai seperangkat rencana dan pengaturan mengenai isi dan materi pelajaran serta cara yang digunakan sebagai pedoman penyelenggaraan KBM (Ibid). Apabila kita mengacu pada Undang-Undang nomor 20 tahun 2003 mengenai Sistem Pendidikan Nasional terdapat dua dimensi kurikulum, pertama, rencana dan pengaturan mengenai tujuan, isi dan bahan pelajaran, kedua, cara yang digunakan untuk kegiatan untuk pelaksanaan pembelajaran (UU, 2003).

Pada dasarnya kurikulum tidak ada begitu saja, dan keberadaan kurikulum juga dibiarkan begitu saja, akan tetapi kurikulum perlu disusun dan disesuaiakan dengan kebutuhan zaman yang ada. Sebab istilah kurikulum tidak hanya sebatas pada jumlah mata pelajaran saja, melainkan meliputi semua pengalaman belajar (learning experiences) yang dialami langsung oleh peserta didik sehingga telah berpengaruh pada karakternya. Definisi dari kurikulum juga telah dihubungkan dengan beberapa dimensi seperti misalnya, dimensi ide, dimensi rencana, dimensi aktivitas dan dimensi hasil (Rouf dan Raghda L, 2018).

Sejak tahun 1945, dalam perjalanan sejarahnya kurikulum pendidikan nasional telah mengalami perubahan. Perubahan tersebut merupakan konsekuensi logis dari terjadinya perubahan sistem politik, ekonomi, budaya, sosial dan iptek dalam masyarakat berbangsa dan bernegara. Kurikulum sebagai seperangkat rencana pendidikan membutuhkan pengembangan secara dinamis sesuai dengan tuntutan dan perubahan zaman yang dialami oleh masyarakat. Kurikulum nasional telah disusun sesuai dengan landasan yang sama, seperti Pancasila dan UUD 1945, yang berbeda hanya pada penekanan pokok dari tujuan pendidikan serta pendekatan dalam mengimplementasikannya (Ahmad, 2018) 
Analisis Materi Buku Siswa ..... Ani Roisatul Muna

Yang dimaksud dengan kurikulum 2013 ialah kurikulum yang baru diterapkan pada tahun pelajaran 2013/2014. Kurikulum ini merupakan pengembangan dari kurikulum yang sudah ada sebelumnya. Pada kurikulum 2013 ini yang menjadi pusat perhatiannya dilihat dari adanya kenaikan dan pengembangan soft skills dan hard skills yang meliput beberapa aspek kompetensi sikap, keterampilan, dan pengetahuan. Terkait dengan hal tersebut, kurikulum 2013 telah berusaha untuk dapat menanamkan nilai-nilai yang tercermin pada sikap yang bisa berbanding lurus dengan keterampilan yang didapat dari siswa melalui wawasan pengetahuan di sekolah. Kurikulum 2013 merupakan kurikulum yang berbasis kompetensi (outcomes-based curriculum) maka dari itu pengembangannya dirumuskan dalam Standar Kompetensi Lulusan. Dilihat dari konstruk dan isinya bahwa, kurikulum 2013 lebih mengutamakan terselenggarannya proses pembelajaran secara interaktif, inspiratif, menantang, menyenangkan, serta memberi motivasi kepada peserta didik untuk ikut berpartisipasi lebih aktif. Di dalam kurikulum 2013 yang menekankan pada dimensi sikap terlebih juga mengharuskan pada pendidik menjadi panutan yang baik, supaya peserta didik dapat memiliki kepribadian yang baik. Guru juga harus memiliki penilaian yang akurat melalui beberapa instrumen yang ada terkait dengan proses penilaian sikap. Dalam kompetensi disini peran guru bukan hanya sebagai penilai, akan tetapi juga sebagai pembangkit perubahan pada peserta didik. Terkait dengan hal itu, hendaknya penilaian tersebut dilakukan secara akurat perorang, sebab penilaian sikap tidak dapat dinilai berdasarkan rata-rata siswa yang ada di dalam kelas (Rouf dan Raghda L, 2018).

\section{Diskripsi Buku Sejarah Kebudayaan Islam Madrasah Aliyah Kelas XI Kurikulum 2013}

Buku Sejarah Kebudayaan Islam yang akan di analisis adalah buku pedoman siswa kelas XI Madrarasah Aliyah. Buku ini telah diterbitkan oleh Kementerian Agama Republik Indonesia. Buku ini disusun oleh M. Husain Tuanaya, Miftachul Ula, Mariyah Ulfah sebagai kontributor naskah, dan Hasibullah Satriawi dan Muhtadin sebagai tim penelaah dimana masing-masing penyusun dan penelaah tetap berada di bawah pengawasan Kementerian Agama Republik Indonesia (KEMENAG RI, 2015).

Dalam buku tersebut terdapat materi isi yang akan diajarkan pada peserta didik yang telah dibagi menjadi kurun waktu dua semester. Pada semester 1 terdiri dari 4 bab, dan pada semester 2 juga dibagi menjadi 4 bab. Materi pelajaran yang akan diberikan pada kelas XI antara lain:

\section{Semester 1 (Bani Umayyah I)}

BAB 1: Proses Lahirnya dan Fase-Fase Pemerintahan Bani Umayyah

1. Proses Lahir dan Fase-Fase Pemerintahan Bani Umayyah I Damaskus

2. Khalifah-Khalifah Bani Umayyah yang Terkenal

3. Kebijakan-Kebijakan Pemerintahan Bani Umayyah I di Damaskus

BAB II: Khalifah-Khalifah yang Terkenal dan Kebijakan Pemerintahan Bani Umayyah 1 
Analisis Materi Buku Siswa ..... Ani Roisatul Muna

1. 14 Khalifah Bani Umayyah 1 yang Berkuasa

2. Khalifah-Khalifah Bani Umayyah yang Terkenal

3. Kebijakan-Kebijakan Pemerintahan Bani Umayyah 1 Damaskus

BAB III: Perkembangan Peradaban Bani Umayyah 1 Damaskus

1. Proses Kodifikasi Hadits Masa Khalifah Umar Bin Abdul Aziz

2. Proses Perkembangan Ilmu Pengetahuan Masa Bani Umayyah 1

3. Peradaban yang Tumbuh pada Masa Bani Umayyah 1

BAB IV: Masa Kelemahan sampai Runtuhnya Bani Umayyah 1 Damaskus

1. Faktor-Faktor Penyebab Mundurnya Bani Umayyah 1

2. Faktor-Faktor Pemicu Munculnya Pemberontakan

3. Kelebihan dan Kekurangan Bani Umayyah 1

4. Proses Runtuhnya Bani Umayyah 1 di Damaskus

Semester II (Bani Abbasiyah)

BAB V: Proses Lahirnya dan Fase-Fase Pemerintahan Bani Abbasiyah

1. Proses Lahirnya Abbasiyah

2. Fase-Fase Pemerintahan Bani Abbasiyah

BAB VI: Khalifah-Khalifah Abbasiyah yang Terkenal dan Kebijakan Pemerintahan Abbasiyah

1. Khalifah-Khalifah Abbasiyah yang Terkenal

2. Kebijakan Khalifah Abbasiyah

BAB VII: Proses Perkembangan Ilmu Pengetahuan Masa Bani Abbasiyah

1. Suasana Tumbuhnya Peradaban Ilmu Pengetahuan Masa Abbasiyah

2. Bentuk Peradaban Hasil Riset dari Para Ahli dan Tokoh-Tokohnya

3. Pusat-Pusat Peradaban Masa Bani Abbasiyah

4. Pengaruh Peradaban Islam Terhadap Dunia Barat

BAB VIII: Proses Perkembangan Ilmu Pengetahuan Masa Bani Abbasiyah

1. Faktor Penyebab Munculnya Pemberontakan Masa Abbasiyah

2. Faktor Penyebab Runtuhnya Bani Abbasiyah

Adapun peta konsep yang diberikan di buku tersebut antara lain:

Semester 1: Bani Umayyah 1

1. Latar Belakang Lahirnya

2. Proses Lahirnya

3. Kebijakan Khalifah

4. Khalifah-Khalifah yang Memerintah

5. Khalifah yang Terkenal 
Analisis Materi Buku Siswa ..... Ani Roisatul Muna

6. Perkembangan Peradaban Ilmu Pengetahuan

7. Tokoh-Tokoh Ilmu Pengetahuan

8. Pusat-Pusat Peradaban

9. Faktor-Faktor Penyebab Runtuhnya

10. Proses Runtuhnya

\section{Semester II: Bani Abbasiyah}

1. Latar Belakang Lahirnya

2. Proses Lahirnya

3. Khalifah-Khalifah yang Memerintah

4. Khalifah yang Terkenal

5. Kebijakan Khalifah

6. Perkembangan Peradaban Ilmu Pengetahuan

7. Tokoh-Tokoh Ilmu Pengetahuan

8. Pusat-Pusat Peradaban

9. Pengaruh Peradaban Islam Terhadap Dunia Barat

10. Faktor-Faktor Penyebab Runtuhnya.

Berdasarkan pemaparan di atas, sangat jelas bahwa dalam buku itu telah menjelaskan mengenai proses pembelajaran yang dimulai dari proses pengamatan, perenungan, menghubungkan dan menalar, ibrah yang dapat diteladani. Dengan adanya peta konsep tersebut juga dapat memberikan kemudahan pada peserta didik untuk bisa menambah pengetahuannya. Setelah kegiatan tersebut selesai dilakukan, maka akan diberikan tes dalam bentuk tanya jawab yang diberikan pada peserta didik, hal itu bertujuan untuk dapat mengetahui seberapa jauh dalam memahami materi yang telah disajikan.

\section{Analisis Urutan Materi Sejarah Kebudayaan Islam}

Dalam melakukan proses analisis urutan materi pada masing-masing bab yang terdapat di buku tersebut, maka peneliti juga akan menggali dari segi Kompetensi Inti dan Kompetensi Dasar yang ada di dalam buku tersebut, dimana peneliti akan mencari kesesuaian Kompetensi Inti dan Kompetensi Dasar sudah sesuai atau belum. Berikut pemaparan analisis yang ada pada setiap bab yang terdapat dalam buku tersebut antara lain:

\section{Keterangan Analisis}

\section{Semester Ganjil}

Bab I $\quad:$ : $\quad$ Pada buku tersebut telah berisi gambaran mengenai isi materi tentang Proses lahirnya dan fase-fase pemerintahan Bani Umayyah yang hendak disajikan cukup jelas, ringkas, dan runtut. 


\begin{tabular}{|c|c|c|}
\hline Bab II & : & $\begin{array}{l}\text { Di dalam buku tersebut, telah dijelaskan mengenai } 14 \text { khalifah yang terkenal } \\
\text { dan kebijakan dari pemerintahan Bani Umayyah } 1 \text {, yang berisi tentang } \\
\text { kesuksesan yang diperoleh dari para khalifah yang terkenal itu, serta } \\
\text { dijelaskan mengenai kebijakan-kebijakan dari pemerintahan Bani Umayyah } \\
\text { di Damaskus. Namun, pada bab ini masih terdapat kekurangan yakni tidak } \\
\text { dijelaskan asal mula dan proses dalam memperoleh prestasi tersebut. }\end{array}$ \\
\hline Bab III & : & $\begin{array}{l}\text { Isi materi yang disajikan pada bab tersebut telah menggambarkan secara rinci } \\
\text { mengenai perkembangan peradaban Bani Umayyah } 1 \text { di Damaskus, namun } \\
\text { pada bab ini masih terdapat kekurangan yakni tidak dijelaskan latar belakang } \\
\text { berdirinya departemen. }\end{array}$ \\
\hline Bab IV & : & $\begin{array}{l}\text { Di dalam bab tersebut telah dijelaskan secara berurutan mulai dari masa } \\
\text { kelemahan hingga runtuhnya Bani Umayyah } 1 \text { di Damaskus. }\end{array}$ \\
\hline \multicolumn{3}{|c|}{ Semester Genap } \\
\hline $\mathrm{Bab} \mathrm{V}$ & : & $\begin{array}{l}\text { Materi yang dijelaskan di dalam buku sudah cukup jelas dan ringkas. Dimana } \\
\text { pada bab tersebut telah menjelaskan mengenai proses lahirnya Abbasiyah dan } \\
\text { fase-fase pemerintahannya yang cukup lengkap. }\end{array}$ \\
\hline Bab VI & : & $\begin{array}{l}\text { Di dalam bab tersebut telah menjelaskan mengenai beberapa khalifah yang } \\
\text { terkenal dan kebijakan dari khalifah tersebut. Dimana pada penjelasan } \\
\text { tersebut sudah dijelaskan mulai dari latar belakang seorang khalifah, hingga } \\
\text { masa pemerintahan. }\end{array}$ \\
\hline Bab VII & : & $\begin{array}{l}\text { Materi telah dijelaskan secara jelas dan sistematis sesuai dengan yang dibahas. } \\
\text { Namun, pada bab itu ada kekurangan yakni pada bagian bahasan tentang } \\
\text { bentuk peradaban hasil riset dari para ahli dan tokoh-tokohnya telah berhasil } \\
\text { menemukan berbagai ilmu pengetahuan, seharusnya pada masing-masing } \\
\text { ilmu pengetahuan yang sudah disebutkan harus dijelaskan lebih rinci lagi, } \\
\text { seperti konsep dari ilmu pengetahuan seperti apa, karena disitu hanya } \\
\text { dijelaskan inti-intinya saja. }\end{array}$ \\
\hline Bab VIII & : & $\begin{array}{l}\text { Dalam bab tersebut telah dijelaskan sesuai dengan topik yang akan dibahas. } \\
\text { Namun masih ada kekurangan yaitu gambaran terjadinya pemberontakan } \\
\text { Abbasiyah hanya dijelaskan pada point-pointnya saja, dan bahasan tentang } \\
\text { perang salib, serangan dari tentara Mongol, berdiri Turki Usmani disitu tidak } \\
\text { dijelaskan latar belakang terjadinya peristiwa, dan ibrah yang dapat diambil } \\
\text { dari peristiwa tersebut. }\end{array}$ \\
\hline
\end{tabular}

Berdasarkan dari hasil analisis yang dilakukan di atas, maka dapat disimpulkan bahwa dalam buku Sejarah Kebudayaan Islam Madrasah Aliyah kelas XI terbitan Kemenag Kurikulum 2013, yang menjadi salah satu kekurangan dari buku tersebut adalah pada setiap materi yang disajikan meskipun cukup mudah untuk dipahami karena sudah ringkas dan jelas, namun pada buku teks tersebut tidak memaparkan sebuah dalil baik berupa ayat Al-Qur'an maupun hadits yang berguna sebagai pendukung pada tiap pembahasan yang diuraikan. Dengan demikian, dari hasil analisis tersebut, maka penulis dapat memberikan saran pada buku Sejarah Kebudayaan Islam Madrasah Aliyah kelas XI terbitan Kemenag Kurikulum 2013 sebagai berikut:

1. Hendaknya mata pelajaran Sejarah Kebudayaan Islam tidak hanya terpacu pada perang yang dilakukan oleh Nabi Muhammad Saw, sahabat, dan orang-orang di zaman Nabi Muhammad Saw. Namun, seharusnya mata pelajaran tersebut bisa memberikan makna dibalik perang itu dan faktor 
apa yang melatar belakangi peperangan tersebut. Sehingga dapat dijadikan sebuah pelajaran bagi umat Islam buat kedepanya nanti.

2. Mata pelajaran Sejarah Kebudayaan Islam sampai saat ini tidak memberikan kajian yang jelas terkait dengan kondisi Dinasti Umayyah dan Dinasti Abbasiyah yang dikenal sebagai dinasti yang memiliki kekuatan yang lebih tinggi dengan segala ilmu pengetahuan dan teknologi yang dimiliki pada saat itu hingga mengalami keruntuhan. Dengan begitu, akan menjadi pertanyaan bagi kita mengapa perkembangan ilmu pengetahuan dan teknologi saat itu sudah tidak bisa bangkit lagi hingga sampai saat ini. Maka dari itu, sebaiknya untuk memperbaiki peradaban Islam di masa yang mendatang agar bisa menjadi maju dan berdaya saing, maka seharusnya dapat mulai membangun peradaban Islam mulai dari sekarang.

3. Pada mata pelajaran Sejarah Kebudayaan Islam seharusnya tidak hanya menyajikan materi pada masa lampau saja, akan tetapi harus disertai dengan peristiwa yang benar-benar aktual, sehingga dapat dijadikan pelajaran untuk masa yang akan mendatang.

4. Buku Sejarah Kebudayaan Islam hendaknya disusun dengan sesuatu yang bisa mengedukasi dengan baik, dengan begitu akan memudahkan bagi guru dalam proses pembelajaran dan dapat mencapai tujuan pembelajaran yang diinginkan. Sekaligus, bagi guru hendaknya dapat menjadi pendidik yang baik dan berkualitas yaitu dapat memilih dan mempertimbangkan dari banyaknya materi yang disajikan dengan baik, agar peserta didik dapat mencapai tujuan pembelajaran yang diharapkan dan kualitas pendidikan juga akan semakin maju.

\section{KESIMPULAN}

Berdasarkan penjelasan di atas maka penulis akan menyimpulkan bahwa, buku Sejarah Kebudayaan Islam dalam kurikulum 2013 ini telah memberikan kemudahan bagi pembaca. Namun, buku ini juga masih perlu adanya perbaikan buat kedepanya. Selain itu, buku ini juga semestinya harus terus bisa meningkatkan kualitas, sebab melalui buku ini yang nantinya siswa dapat mengembangkan wawasan belajarnya dengan baik. Disamping itu, diharapkan pada buku ini dapat memperbaiki dari kesalahan-kesalahan yang terjadi. Karena, buku teks tidak hanya dilihat dari sudut pandang tertentu saja, akan tetapi buku teks juga harus mampu menarik minat pembaca yang menggunakannya dan dapat memberi motivasi kepada para pembacannya. Dengan demikian, dapat kita ketahui bahwa begitu pentingnya penggunaan buku teks siswa dalam pelaksanaan proses pembelajaran. Jika buku teks tergolong baik dan layak untuk dibaca oleh siswa, maka nantinya akan menghasilkan keberhasilan dalam proses pembelajaran dan juga dapat mencapai tujuan pembelajaran yang diharapkan. 


\section{DAFTAR PUSTAKA}

A'la, Abd. 2006. Pembaruan Pesantren. Yogyakarta: LKiS.

Abdurrachman, dkk. 2001. Paradigma Pendidikan Islam. Yogyakarta: Pustaka Belajar.

Ahmad, Syarwan. 2018. Problematika Kurikulum 2013 dan Kepemimpinan Intruksional Kepala Sekolah, Jurnal Pencerahan. Vol. 8. No. 2.

Ariyunita, Noorrela. 2019. Pemetaan dan Analisis Maharah Mata Pelajaran Sejarah Kebudayaan Islam (SKI) Jenjang SMA dan MA (Permendikbud No. 24 Tahun 2016 dan KMA No. 165 Tahun 2014). Literasi: Jurnal Ilmu Pendidikan. Vol.9 No.2. hal-98-104.

Basyirudin, M. 2002. Media Pembelajaran. Jakarta: Ciputat Press.

Darmayanti, Vivi, Slamet H, dan Sulifah A.H. 2014. Pengembangan Buku Siswa Berbasis Inkuiri Pada Pokok Bahasan Pencemaran dan Kerusakan Lingkungan Untuk Meningkatkan Hasil Belajar Siswa Kelas VII SMP Negeri 1 Maesan Bondowoso. Pancaran Pendidikan. Vol. (3) 3. hal. 93-102.

Departemen Agama RI. 2009. Pembelajaran Sejarah Kebudayaan Islam. Jakarta: Direktorat Jenderal Pendidikan Islam.

Imam Barnadib. 1987. Filsafat Pendidikan. Yogyakarta: FIP IKIP Yogyakarta.

Lubab, Manarul. 2015. Analisis Kelayakan Isi Buku Teks Siswa Pendidikan Agama Islam dan Budi Pekerti SMA/MA Kelas X Kurikulum 2013 Terbitan Kementrian Pendidikan dan Kebudayaan Tahun 2014. Diss. Uin Walisongo.

Mida, Muzamiroh. 2013. Kupas Tuntas Kurikulum 2013. Jakarta: Kata Pena.

Moleong, J Lexy. 2012. Metode Penelitian Kualitatif. Bandung: Remaja Rosdakarya.

Muaripin. 2018. Kajian Pengembangan Bahan Ajar Melalui Analisis KI dan KD dalam Mata Pelajaran SKI Pada Madrasah Tsanawiyah (MTs). Tatar Pasundan: Jurnal Diklat Keagamaan, Vol. (12) 33.

Rokhman, Wakhid. 2017. Analisis Buku Siswa Sejarah Kebudayaan Islam Kelas X. Diss. Universitas Islam Negeri Maulana Malik Ibrahim.

Rouf, Abdul dan Raghda L. 2018. Peranan Guru dalam Implementasi Kurikulum 2013 di Madrasah Ibtidaiyah Negeri 1 Jombang. Sumbula: Jurnal Studi Keagamaan, Sosial dan Budaya. Vol. (3)2. hal. 903-926.

Trianto. 2014. Model Pembelajaran Terpadu: Konsep, Strategi dan Implementasinya dalam KTSP. Jakarta: PT Bumi Aksara.

Zed, Mestika. 2008. Metode Penelitian Kepustakaan. Jakarta: Yayasan Obor Indonesia. 